\title{
Da funcionalidade e limitações do pedido de restituição ordinária e sua aplicabilidade aos contratos na falência: uma análise da ineficácia da cláusula resolutiva expressa
}

\author{
Functionality and limitations of the ordinary request for \\ refund and its applicability to the contracts in debtor's \\ bankruptcy: an analysis of the ineffectiveness of \\ express termination clause
}

\section{Alexandre Ferreira de Assumpção Alves*}

\section{Resumo}

Através de pesquisa classificada como aplicada, qualitativa, explicativa e bibliográfica, analisam-se questões relevantes envolvendo o pedido de restituição ordinária disciplinado na Lei no 11.101/2005 (lei brasileira de falência e recuperação de empresas) e sua função precípua: a retomada da posse direta da coisa pelo titular do domínio. O direito de propriedade, reconhecido como direito fundamental nos termos do art. $5^{\circ}, \mathrm{XXII}$, da Constituição da República Brasileira, permite ao proprietário usar, gozar e dispor da coisa, e, sobretudo, o direito de reavê-la de quem a tenha injustificadamente, na forma do art. 1.228 do Código Civil atual, tal qual fazia o art. 524 do Código Civil anterior. Observase que este direito de reaver a propriedade deve estar limitado à função social dos contratos que impõem aos contratantes que estes almejem, para além dos seus interesses individuais, a satisfação de interesses extracontratuais socialmente relevantes. Destarte, partindo de uma análise histórica do instituto, estudam-se, através do método indutivo, algumas espécies de contratos em que se vislumbraria o cabimento do pedido de restituição e eventual conflito entre a cláusula resolutiva expressa, que funcionaliza o pedido de restituição, e a função social dos contratos, à luz dos interesses da massa falida e dos demais credores.

Doutor em Direito. Professor associado de Direito Comercial nas Faculdades de Direito da Universidade Federal do Rio de Janeiro e Estadual do Rio de Janeiro. Rio de Janeiro - RJ Brasil. E-mail: asaa@uol.com.br. 
Palavras-chave: Restituição ordinária. Falência. Propriedade (Direito de). Contratos. Cláusula resolutiva.

\section{Abstract}

Through classified as applied, qualitative, explanatory and bibliographical research, relevant issues involving ordinary request for refund of brazilian Law number 11.101/2005 are analyzed. The right to property is recognized as a fundamental right under art. 5, XXII of the Constitution, allows the owner to use, usufruct and dispose of the thing, and especially the right to reclaim it from those who have aquire unjustifiably, according to art. 1228 of the Civil Code, as did the art. 524 of the brazilian Civil Code of 1916. Thus, the ordinary request for refund is a corollary of the constitutional right of property that allow others parties to resume their property, which were unfairly collected in the debtor's bankruptcy. It was also noted that the right to repossess the property must be limited to the social function of contracts which requires contractors that they hanker, beyond their individual interests, the satisfaction of socially relevant interests. Thus, starting from a historical analysis of the institute, we study according to the inductive method, certain kinds of contracts in which descry the pertinence of the request for refund. Just like the conflict between the express termination clause, which functionalizes the request for refund, in contrast to the social function of contracts in the interests of the estate and other creditors.

Keywords: Ordinary refund. Bankruptcy. Property (Right of). Contracts. Termination clause.

\section{Introdução}

A atual Lei de Falências e Recuperação de Empresas, Lei $n^{\circ} 11.101 / 2005$, tem por viés precípuo a manutenção da atividade empresária e a preservação da unidade produtiva que se demonstre viável, como forma de resguardar um equilíbrio entre as dificuldades do devedor, os direitos do credor e a atividade empresarial ${ }^{1}$. Entretanto,

"Art. 75. A falência visa preservar e otimizar a utilização produtiva dos bens, ativos e recursos produtivos, inclusive os intangíveis, da empresa." (grifos nossos) 
nem sempre será possível manter a atividade empresarial ativa como se pretende, pois o empresário pode estar imiscuído por completo em dívidas e obrigações não adimplidas, de modo a inviabilizar a manutenção de sua empresa.

Destarte, atento aos novos ditames da atividade empresarial e dos fundamentos da ordem econômica constitucional, notadamente a função social da empresa (art. 170, III), o legislador incumbiu-se de privilegiar o tratamento preventivo à quebra nas situações em que a empresa, embora passando por graves percalços, ainda é viável e não deve ser dissolvida de pronto. Com isso, preservam-se os interesses tanto do empresário, sócios, colaboradores e interessados em seu soerguimento, como fornecedores, empregados, credores e até mesmo do próprio Estado.

Todavia, nem sempre é possível ou eficaz o procedimento recuperatório. Há situações em que a crise está instaurada há muito tempo ou o descrédito é tamanho que não há outra alternativa senão o pedido de falência. Nesse diapasão, não sendo possível elidir a impontualidade crônica ou tendo o próprio empresário verificado a inviabilidade do pedido de recuperação², será decretada sua falência.

Ocorrendo isso, em razão do princípio da universalidade (art. 103 da Lei $\left.n^{\circ} 11.101 / 05\right)$, os bens do falido serão arrecadados para posterior alienação judicial em prol do pagamento aos credores, de acordo com a ordem de preferência legal, e de maneira proporcional, pro rata, seguindo princípios que perseguirão um rateio equânime (par conditio creditorum).

Durante a execução da etapa arrecadatória no processo falimentar, devem ser incluídos no auto elaborado pelo administrador judicial bens

2 Conforme art. 105 da Lei $n^{0}$ 11.101।05: "O devedor em crise econômicofinanceira que julgue não atender aos requisitos para pleitear sua recuperação judicial deverá requerer ao juízo sua falência, expondo as razões da impossibilidade de prosseguimento da atividade empresarial". 
que, embora em poder do devedor, sejam de titularidade de terceiros. Isso ocorre porque não cabe ao administrador judicial perquirir quais os bens compõem ou quais não compõem o patrimônio do devedor. Dada função cabe ao juízo falimentar, que deverá destacar esses bens da massa e restituí-los ao seu real proprietário. Dessa forma, tendo o terceiro sido atingido em seu direito de propriedade com o ato constritivo, cabe-lhe ingressar no juízo falimentar com o pedido de restituição para reaver o bem.

Com esse escopo, a restituição de bens injustificadamente incorporados à massa falida emerge como uma fase essencial ao processo falimentar, pois, através desta, fica a massa falida impedida de se valer de patrimônio alheio para saldar as dívidas do devedor, o que configuraria um locupletamento ilícito. Da mesma forma, ao pedido de restituição cabe salvaguardar a propriedade de terceiros de constrições injustificadas, função capital na reafirmação do Estado Democrático de Direito instituído pela ordem constitucional vigente.

Sendo assim, o estudo do pedido de restituição revela-se preponderante para que se cumpra a ratio da Lei de Falências e Recuperações e do ordenamento jurídico como um todo. Para tanto, só caberá ao proprietário do bem a faculdade de reavê-lo, afinal, como se pretende demonstrar, o instituto restitutório é um corolário inafastável do direito constitucional de propriedade. Em outras palavras, a propriedade é o paradigma do instituto.

Não obstante, ponto relevante da pesquisa é a análise do conflito entre a cláusula contratual resolutiva em caso de decretação da falência do devedor como causa extintiva, de pleno direito, dos contratos com este celebrado e a função social dos contratos. Como se vislumbra, ao passo que a mencionada cláusula funcionaliza o pedido de restituição ao permitir seu exercício imediato, esta, inexoravelmente, mitigará a função social dos contratos. Eis que findará sua vigência, dada a extinção de pleno direito por força da verificação da condição.

Vale-se o presente trabalho do método indutivo e da análise histórico-analítica do pedido de restituição ordinária, realizando, através 
do estudo da evolução legislativa, um comparativo do referido instituto desde a sua concepção até o seu estágio atual. Pretende-se analisar as divergências jurisprudenciais e doutrinárias quanto ao pedido de restituição ordinária, com o escopo de identificar quais as hipóteses de cabimento e os seus efeitos em relação ao processo falimentar.

\section{Evolução legislativa do pedido de restituição}

Ao regular as Quebras na Parte Terceira, previa o Código Comercial (Lei n 556/1850), em seu art. 874³ , a figura do credor de domínio, isto é, aquele que detinha o domínio sobre algum bem arrecadado na falência. Asseverava ainda o Código que, não restando dúvida sobre a condição de proprietário, os reclamantes receberiam a coisa.

O instrumento processual hábil para assegurar a entrega era a ação de reivindicação, disciplinada na lei civil. Tratava-se da única exceção legal à suspensão das execuções contra a massa, conforme art. 8304, o que era plenamente plausível, haja vista ter o instituto a finalidade de proteger o direito de propriedade no âmbito civil, e não exclusivamente no falimentar. Destarte, poderia a desintegração de um bem da massa

3 "Art. 874: Pertencem à classe de credores do domínio: 1 - Os credores de bens que o falido possuir por título de depósito, penhor, administração, arrendamento, aluguel, comodato, ou usufruto; [...] 2 - Os credores de mercadorias em comissão de compra ou venda, trânsito ou entrega; 3 - Os credores de letras de câmbio, ou outros quaisquer títulos comerciais endossados sem transferência da propriedade (art. 361 n. 3); [... 8- O vendedor antes da entrega da coisa vendida, se a venda não for a crédito (art. 198)."

4 "Art. 830: As execuções que ao tempo da declaração da quebra se moverem contra comerciante falido ficarão suspensas até a verificação dos créditos, não excedendo de trinta dias, sem prejuízo de quaisquer medidas conservatórias dos direitos e ações dos credores privilegiados ou hipotecários. Se a execução for de reivindicação (art. 874), prosseguirá, sem suspensão, com o Curador fiscal. Todavia, se os bens executados se acharem já na praça com dia definitivo para sua arrematação fixado por editais, o Curador fiscal, com autorização do Juiz comissário, poderá convir na continuação, entrando para a massa o produto se a execução proceder de créditos que não sejam privilegiados nem hipotecários, ou o remanescente procedendo destes." 
falida ocorrer tão logo tenha sido selado o estabelecimento ${ }^{5}$, pois a ação civil poderia já ter reconhecido o direito de propriedade do terceiro e, por consequência, a faculdade de reivindicá-lo.

Tais dispositivos eram recorrentemente criticados pela doutrina ${ }^{6}$, dada a imprecisão técnica do legislador. Os terceiros donos de bens arrecadados na falência não são credores da massa falida, inexistindo relação creditícia a ser tutelada. Não há, portanto, "crédito de domínio", como dispôs o legislador. Da mesma forma, o emprego da ação reivindicatória era impróprio, pois a reivindicação na falência não se limita à proteção do direito de propriedade, como tem por escopo o instituto civilista; em matéria falimentar, a tutela se estende às relações obrigacionais e pessoais dos terceiros.

Com a edição do Decreto-Lei n 917/1890, passou o legislador, no art. $68^{7}$, a denominar o dono de bem arrecadado de "credor reivindicante", ao arrepio da crítica doutrinária ${ }^{8}$. Determinava ainda 0 texto legal, em seu art. 150, que ao credor reivindicante seria concedido o prazo de 3 dias para se manifestar, devendo, na oportunidade, trazer aos autos prova inequívoca de seu domínio, o que de pronto exaspera

5 Neste ponto, cabe um esclarecimento: determinava o art. 809 do Código Comercial que, na sentença da abertura da quebra, o Tribunal de Comércio deveria ordenar que se apusessem selos em todos os bens do falido, como forma de torná-los indisponíveis. Tal procedimento tem ímpar influência do direito italiano, onde se dá grande importância à aposição de selos no estabelecimento comercial e nos bens do falido que serão arrecadados.

6 Por todos, José Xavier Carvalho de Mendonça (1934), que em diversas passagens de sua obra critica os dispositivos.

7 "Art. 68: São credores reivindicantes, quer tenham ação real ou rei-persecutoria quer não, propriedade plena ou jus in re: a) o dono de cousa adquirida pelo falido de quem não era o proprietário; b) o dono de cousa em poder do falido por titulo de deposito, penhor, anticrese, administração, arrendamento, comodato, usufruto, uso e habitação; c) os donos de mercadoria em comissão de compra ou venda, transito ou entrega; d) dono de cousa, embora fungível, em poder do falido por efeito de mandato, inclusive dinheiro, efeitos de comércio ou títulos a eles equiparados, endossados sem transferência de propriedade, ainda não pagos ou em poder de terceiro em nome do falido na época da falência".

8 Leciona Mendonça (1934, p. 274): "Se a própria expressão reivindicantes não evita censura, estas outras - credores de domínio, credores reivindicantes - são inegavelmente impróprias e ante-jurídicas, porque o dono da cousa não é credor de quem a possue; tem um jus in re, e não um jus ad rem, ou melhor não a recebe, em pagamento, a título de credor, mas, em restituição, a titulo de proprietário." 
o caráter incidental do hodierno pedido de restituição, que sabidamente não se presta a dirimir conflito de propriedade. Sem embargo, não sendo apresentada contestação e não havendo dúvida sobre o domínio da coisa, poderia o síndico (hoje, administrador judicial) promover a entrega do bem arrecadado, como definia o art. $68, \S 3^{\circ}$ do Decreto-Lei $n^{\circ} 917 / 1890$.

Em 1908, passou o instituto a ser regulado pela Lei $n^{\circ} 2.024$, que em seu art. $138^{\circ}$ adotou a denominação "reivindicante", o que igualmente não passava ao largo da censura doutrinária. Por outro lado, ciente da crítica doutrinária, o legislador expressamente previu o manejo do instituto na proteção dos direitos pessoais, tentando, assim, por via oblíqua, corrigir a inconsistência jurídica da nomenclatura.

O Decreto $n^{\circ} 5.746 / 1929$ repetiu o mesmo nomem iuris do diploma que revogara em seu art. $138^{10}$, o que não calou a doutrina, como se denota da lição de Ferreira (1966, p. 92):

[...] a reivindicação admitida no processo de falência não se reduz apenas à ação promovida pelo titular da propriedade, para restituição da coisa a seu dono. Estende-se, em rigor, à restituição pleiteada por quem, a título de direito real ou de contrato, tenha o direito de reaver a coisa arrecadada em poder do falido.

$9 \quad$ "Art. 138: Poderão ser reivindicados na falência os objetos alheios encontrados em poder do falido, e também, nos seguintes casos espécies, ainda que fundados em um direito pessoal: 1 . As cousas em poder do falido a titulo de mandato, deposito regular, penhor, anticrese, administração, arrendamentos comodato, usufruto, uso e habitação. 2. As mercadorias em poder do falido a titulo de comissão de compra ou venda, transito ou entrega. Cessará a reivindicação si as mercadorias tiverem sido vendidas e o preço creditado em conta corrente por autorização ou ordem do dono. 5. As cousas vendidas a credito nas vésperas da falência e ainda em poder do falido, tendo sido o vendedor induzido por dolo ou fraude do mesmo falido."

10 "Art. 138: Poderão ser reivindicados na concordata preventiva e na falência os objetos alheios encontrados em poder do falido, e também, nos seguintes casos, ainda que fundados em um direito pessoal. $1^{\circ}$ As cousas em poder do falido a título de mandato, deposito regular, penhor, anticrese, administração, arrendamento, comodato, usufruto, uso e habitação. $2^{\circ}$ As mercadorias em poder do falido a título de comissão de compra ou venda, transito ou entrega. Cessará a reivindicação si as mercadorias tiverem sido vendidas e o preço creditado em conta corrente por autorização ou ordem do dono". 
No entanto, a partir de 1945, seguindo a orientação do mesmo autor passou-se a prever a reclamação reivindicatória também para a concordata preventiva, que só seria extinta pela Lei $n^{0} 11.101 / 2005 .{ }^{11}$

Não obstante, é preciso destacar que todos os regramentos anteriores a 1945 traziam em seu bojo um rol extenso de hipóteses de cabimento da ação reivindicatória, englobando, por vezes, grande parte dos credores da massa falida. Os tribunais pátrios, por sua vez, alargavam ainda mais o âmbito da reclamação reivindicatória, depauperando, com isso, o patrimônio falido, de modo a não permitir, comumente, qualquer magro rateio aos quirografários (VALVERDE, 2001).

O Decreto-Lei $n^{\circ} 7.661 / 1945$ consagrou, enfim, o uso da expressão "pedido de restituição", em seu art. $76^{12}$. Delimitou o legislador que o pedido de restituição "ou se alicerça em direito real, isto é, na propriedade em qualquer de suas manifestações, ou em relação de obrigação preexistente à falência, ou desta decorrente, a qual assegura ao reclamante o direito de reaver a coisa arrecadada" (VALVERDE, 2001, p. 32). Destarte, estava superada a crítica de outrora; o pedido de restituição era agora o meio próprio a perquirir a restituição de um bem.

A atual Lei de Falências e Recuperação de Empresas manteve o nomen juris na Seção II do Capítulo II, "Do pedido de restituição". Dessa forma, os bens que vierem a sofrer constrição judicial por estarem em poder do falido, mas que sejam de titularidade de terceiros, devem ser destacados da massa falida objetiva.

O pedido de restituição, antes ação reivindicatória, deveria ser proposto no juízo que determinara a quebra, não podendo o

11 Sugeria Ferreira (1932, p. 172): "antes de tudo aconselha que também se permita a reivindicação no processo da concordata preventiva, principalmente das coisas vendidas a crédito na véspera do requerimento desta, e ainda em poder do devedor. Inúmeros são os casos de comerciantes que, dias antes do requerimento de convocação dos credores, para lhes propor concordata preventiva, compram mercadorias, já com o intuito de não pagar".

12 "Art. 76: Pode ser pedida a restituição de coisa arrecadada em poder do falido quando seja devida em virtude de direito real ou de contrato. $\S 1^{\circ} \mathrm{A}$ restituição pode ser pedida, ainda que a coisa já tenha sido alienada pela massa." 
representante da massa falida oficiosamente proceder à entrega em entendendo ser esta devida.

Apontam alguns autores, dentre eles Lacerda (1961), que a verificação da titularidade dos bens só poderia se dar "judicialmente, a fim de se evitar conluios para a subtração de valores". Nesse diapasão, o legislador tipificou penalmente a conduta do administrador, que oficiosamente procede à restituição no art. 172 da Lei n ${ }^{\circ} 11.101 / 2005$ (correspondente ao inciso II do art. 188 do Decreto-Lei $n^{\circ}$ 7.661/1945) como forma de tolher tal comportamento, dada sua nocividade ao concurso de credores. Em posição diametralmente oposta se encontra Campinho (2009, p. 390), o qual, seguindo o modelo francês ${ }^{13}$, defende que:

[...] a Lei $n^{\circ} 11.101 / 2005$ não evoluiu, em nosso sentir, adequadamente no tema. Somos partidários de um posicionamento mais liberal sobre a restituição de bens e valores. Pensamos que seria útil se processasse administrativamente perante o administrador judicial que, com a autorização do juiz, após a oitiva do comitê de credores, pudesse promover a restituição. A obrigatoriedade do procedimento judicial não contribui para as tão decantadas economia processual e celeridade do processo de falência (parágrafo único do artigo 75 ), pois diversos incidentes deverão ser processados, ocupando, muitas vezes, desnecessariamente, a máquina judicial.

Tratando-se de pedido de restituição, todas as medidas de cautela devem ser empregadas, pois a devolução de um bem que intuitivamente pertença à massa falida desnaturaria a garantia da par conditio creditorum. Ademais, a necessidade de ratificação judicial demandaria

13 Na legislação francesa, o pedido de restituição se dá administrativamente perante o administrador, como define o "article L624-17: L'administrateur avec l'accord du débiteur ou à défaut le débiteur après accord du mandataire judiciaire peut acquiescer à la demande en revendication ou en restitution d'un bien visé à la présente section. A défaut d'accord ou en cas de contestation, la demande est portée devant le juge-commissaire qui statue sur le sort du contrat, au vu des observations du créancier, du débiteur et du mandataire de justice saisi." 
ao juiz a mesma análise que hoje é feita quando oposto um pedido de restituição, sendo a demora na prestação jurisdicional um problema exclusivamente forense, ao qual esse eventual pedido de autorização também seria submetido ${ }^{14}$.

A melhor solução para o debate, como prevê a Lei n 11.101/2005, é a prestação de caução pelo terceiro que pretenda rever o bem de sua propriedade antes mesmo da decisão restitutória. Evita-se, com esse expediente, o desvio injustificado de bens da massa falida objetiva, que consubstancia a garantia do pagamento aos credores e, ao mesmo tempo, a possível deterioração do bem do terceiro. No direito português, encontra-se disposição semelhante no art. 145 do Decreto-Lei ${ }^{\circ} 53$ de $2004^{15}$.

Nota-se, então, pela evolução histórica, que tanto o pedido de restituição como a ação revocatória ${ }^{16}$ foram sendo amoldados pelas sucessivas leis falimentares a partir de um instrumento eminentemente civilista, mas incorporado pelo legislador como meio de proteção dos interesses de terceiros prejudicados pela arrecadação de bens.

\section{Pedido de restituição e os contratos do devedor}

Informados pelo princípio da autonomia da vontade, os contratos representam, na lição de Pereira (2009, p. 7), "um acordo de vontades, na conformidade da lei, e com a finalidade de adquirir, resguardar, transferir, conservar, modificar ou extinguir direitos".

14 O modelo italiano de restituição segue esta linha: "Art. 87-bis. Inventario su altri beni: In deroga a quanto previsto dagli articoli 52 e 103, i beni mobili sui quali i terzi vantano diritti reali o personali chiaramente riconoscibili possono essere restituiti con decreto del giudice delegato, su istanza della parte interessata e con il consenso del curatore e del comitato dei creditori, anche provvisoriamente nominato."

15 "Art. 145: 1- Ao reclamante da restituição de coisas móveis determinadas pode ser deferida a sua entrega provisória, mediante caução prestada no próprio processo."

16 A ação revocatória tem por origem histórica o instituto civilista da ação pauliana. 
Nos modelos legislativos de Estados liberais, sobretudo após a Revolução Francesa, mas ainda sob o trauma dos regimes absolutistas recém-extintos, a autonomia privada dos contratos era entendida como a maior expressão da liberdade dos indivíduos, um verdadeiro dogma que não poderia ser tolhido pelo Estado ("qui dit contractuelle, dit juste"17). Na época em que os economistas primavam pela lei da oferta e procura para regular o mercado, acreditava-se que a liberdade criaria relações isonômicas entre os indivíduos naturalmente, sendo desnecessária a intervenção estatal. Esse contexto influenciaria o legislador na edição do Código Civil de 1916, notadamente um código individualista e liberal.

Com a transição do modelo liberal para o social, fruto das profundas transformações sociais e econômicas, percebeu-se que a liberdade, por vezes, criava desequilíbrios. Destarte, deveria o Estado estabelecer regras e princípios que coibissem a liberdade toda vez que ela causasse desigualdades. Mudou-se, assim, o paradigma da liberdade irrestrita para a liberdade vigiada, para o capitalismo social.

Com base nas considerações acima e em princípios como a justiça social, a dignidade da pessoa humana e a função social, foi concebido, aprimorado e aprovado o atual Código Civil (Lei n 10.406/2002), impondo limites às partes e aos contratos por elas entabulados, dentre os quais, a necessidade de atenderem à sua função social, conforme art. 421 do Código $\mathrm{Civil}^{18}$, mitigando, assim, o principio da relatividade, ao impor efeitos que extrapolem a esfera dos contratantes. Nesse ponto, e distante das críticas ${ }^{19}$, a redação dada ao dispositivo diverge da doutrina quanto ao alcance da função social como limite à autonomia privada.

17 Esta frase é atribuída ao filósofo do Direito Alfred Fouillée.

18 "Art. 421. A liberdade de contratar será exercida em razão e nos limites da função social do contrato."

19 A doutrina diverge quanto à redação do art. 421 do Código Civil. Para uma corrente doutrinária, capitaneada por Álvaro Villaça Azevedo, pela redação do dispositivo legal, o legislador impôs a função social como limite à liberdade de contratar, e não à liberdade contratual, que seria o correto. Já para outra corrente, capitaneada por Gustavo José Mendes Tepedino (2009), o dispositivo tem a redação correta, pois a busca de um fim socialmente útil não está relacionada apenas ao conteúdo do contrato, mas, igualmente, ao momento prévio, que é a decisão de contratar ou não. Portanto, a liberdade de contratar tem a função social como limite. 
Para uma corrente de entendimento, trata-se de um conceito jurídico indeterminado, do qual cabe à doutrina e jurisprudência a integração. A função social do contrato não seria dotada de eficácia jurídica independente, mas, por outro lado, deveria ser considerada pelo legislador em seu mister. ${ }^{20}$ Essa posição acaba por esvaziar a importância da função social, uma vez que esta só se manifestaria por intermédio de institutos jurídicos já positivados, e não de forma autônoma.

Há, no entanto, outra corrente de pensamento que entende a função social como um instrumento capaz de impor a terceiros o dever de respeitar e zelar pela relação jurídica firmada entre os contratantes. Dessa forma, não só os contratantes deveriam respeitar o contrato, como se infere do princípio da relatividade, mas também terceiros, que poderiam, devido à função social dos contratos, ser responsabilizados caso contribuíssem com o descumprimento da obrigação firmada por aqueles. Esse foi o entendimento adotado pelo Conselho da Justiça Federal na I Jornada de Direito Civil, consolidado no Enunciado $n^{\circ} 21^{21}$.

Em sentido diametralmente oposto ao que fora concebida a função social, esta segunda posição acaba por dar aos contratantes uma garantia a mais de sua posição contratual. Originalmente, a função social prestava-se a impor limites, e não benesses, aos contratantes, como forma de limitar a liberdade irrestrita criadora de desigualdades. Não obstante, é a boa-fé objetiva que impõe a terceiros que não intervenham prejudicialmente nas relações contratuais das quais não fazem parte, e não a função social do contrato, pois esta é fonte de deveres aos contratantes, e não de direitos.

\footnotetext{
20 Esta parece ser a opinião de Humberto Theodoro Júnior (2003, p.93): "A lei prevê a função social do contrato, mas não a disciplina sistemática ou especificamente. Cabe à doutrina e à jurisprudência pesquisar sua presença difusa dentro do ordenamento jurídico e, sobretudo, dentro dos princípios informativos da ordem econômica e social traçada pela Constituição".

21 Enunciado n 21 - "Art. 421: a função social do contrato, prevista no art. 421 do novo Código Civil, constitui cláusula geral a impor a revisão do princípio da relatividade dos efeitos do contrato em relação a terceiros, implicando a tutela externa do crédito."
} 
Nessa linha de pensamento, defende uma terceira corrente, a qual se filia Gustavo Tepedino (2009, p. 149), que a função social deve ser entendida como princípio que, nas palavras do autor, "impõe às partes o dever de perseguir, ao lado de seus interesses individuais, a interesses extracontratuais socialmente relevantes, dignos de tutela jurídica, que se relacionam com o contrato ou são por ele atingidos". Continua o autor:

Os legítimos interesses individuais dos titulares da atividade econômica só merecerão tutela na medida em que interesses socialmente relevantes, posto que alheios à esfera individual, venham a ser igualmente tutelados. A proteção dos interesses privados justifica-se não apenas como expressão da liberdade individual, mas em virtude da função que desempenha para a promoção de posições jurídicas externas, integrantes da ordem pública. (TEPEDINO, 2009, p. 151)

Nesse ponto, ratifica o legislador a primazia da função social dos contratos, prevendo-a como questão de ordem pública, na forma do art. 2.035, parágrafo único, do Código Civil ${ }^{22}$. Ressalta-se que essa limitação se impõe inclusive aos contratos firmados antes da entrada em vigor do Código Civil, reafirmando a sua proeminência no ordenamento jurídico.

Aplicando-se a consideração supra ao pedido de restituição, percebe-se que o instituto conjuga interesses conflitantes: de um lado, a massa falida esforçando-se para manter o bem arrecadado; e o terceiro, por sua vez, tentando evitar a sujeição ao concurso de credores.

Estabelece o artigo 85, caput da Lei no 11.101/2005, que o proprietário de bem arrecadado no processo de falência ou que se

22 "Art. 2.035. A validade dos negócios e demais atos jurídicos, constituídos antes da entrada em vigor deste Código, obedece ao disposto nas leis anteriores, referidas no art. 2.045, mas os seus efeitos, produzidos após a vigência deste Código, aos preceitos dele se subordinam, salvo se houver sido prevista pelas partes determinada forma de execução. Parágrafo único. Nenhuma convenção prevalecerá se contrariar preceitos de ordem pública, tais como os estabelecidos por este Código para assegurar a função social da propriedade e dos contratos." 
encontre em poder do devedor na data da decretação da falência poderá pedir sua restituição. Trata-se do meio judicial pelo qual o terceiro pode reaver o bem de sua propriedade, como já dispunha o art. 1.228 do Código Civil. "Sendo esse o alicerce de sua pretensão, o reclamante deverá alegar e provar o domínio sobre o bem reivindicado e a posse injusta que sobre ele está sendo exercida" (CAMPINHO, 2009, p. 390). Essa posse injusta pode ser delineada por diversos meios, a depender da espécie do contrato.

Como determina o art. 117 da Lei $n^{\circ} 11.101 / 2005$, os contratos bilaterais ${ }^{23}$ não se resolvem com a falência e, a depender da manifestação do administrador judicial e autorização do Comitê de Credores, caso haja, poderão ser cumpridos. Nessa hipótese, o credor, em até 90 dias da data da assinatura do termo de compromisso do administrador judicial, poderá notificá-lo para que se manifeste em até 10 dias, importando o seu silêncio na extinção do contrato, sem prejuízo de eventuais perdas e danos comprovados, conforme dispõe o art. $117, \S 1^{\circ}$.

Quanto aos contratos unilaterais ${ }^{24}$, a lei faculta ao administrador judicial, com as mesmas razões aplicáveis aos contratos bilaterais, decidir pelo cumprimento do contrato, caso seja autorizado pelo Comitê de Credores, se houver, importando sua inércia na extinção.

Entretanto, com o escopo de afastar essa faculdade que tem o administrador judicial no interesse da massa, tem sido cada vez mais frequente a disposição contratual que prevê a falência como causa de resolução de pleno direito do contrato. Nela, independentemente da manifestação do administrador judicial e do interesse no cumprimento do contrato, na forma dos arts. 117 e 118, o contrato estará extinto com a decretação da falência de uma das partes e, por consequência, a posse da massa sobre o bem seria injusta. Trata-se de uma cláusula

\footnotetext{
23 Contrato bilateral é aquele em que as partes contratantes estão vinculadas a cumprir uma obrigação, uma para com a outra, sendo cada uma credora e devedora ao mesmo tempo.

24 Contrato unilateral é aquele que cria obrigações somente para um dos contratantes. Há nele um credor e um devedor, sem reciprocidade.
} 
contratual que funcionaliza o pedido de restituição ao fundamentá-lo e, como pressuposto lógico, também o direito de propriedade.

No entanto, adstrito a essa disposição contratual, entabulada pelo devedor antes da falência, pode ser que a manutenção da relação contratual favoreça a massa falida e, por conseguinte, o interesse social na destinação produtiva dos bens, um dos objetivos do instituto (art. 75). Nessa hora, estará configurado o conflito entre o interesse da massa falida e a autonomia privada. Em outras palavras, entre o direito de propriedade e a função social dos contratos. Sobre esse ponto, Coelho (2007, p. 313) leciona:

[...] nos contratos interempresariais, costuma constar do instrumento a expressa previsão de resolução na hipótese de falência de um ou qualquer dos contratantes. Se as partes pactuaram cláusula de resolução por falência, esta é válida e eficaz, não podendo os órgãos da falência desrespeitá-la. O direito falimentar, como capítulo do direito comercial, tem normais contratuais de natureza supletiva da vontade dos contratantes; seus preceitos sobre obrigações contratuais só se aplicam se as partes não convencionaram diferentemente. Assim, o contrato se rescinde não por força do decreto judicial, mas pela vontade das partes contratantes, que o elegeram como causa rescisória do vínculo contratual.

Pactua desse entendimento Campinho (2009), que, mesmo prevendo a possibilidade de enfraquecimento da decretação judicial de manutenção da atividade empresária como forma de preservar o ativo, dá prevalência à cláusula resolutiva expressa ${ }^{25}$.

Com a devida vênia, não se pode comungar com esse entendimento de que o interesse da massa deve prevalecer, pois a cláusula resolutiva

25 Assim leciona Campinho (2009, p. 395): "Sendo ela deferida [a continuação provisória do negócio], caberá ao administrador judicial pronunciar-se a respeito da execução do contrato, salvo se houver cláusula expressa prevendo a falência como causa de extinção da relação contratual. Neste caso, em especial, pode ficar prejudicada a própria eficácia da manutenção da atividade. 
expressa é tida como ineficaz em relação à massa falida. É notório que a mencionada cláusula não se coaduna com a sua função social do contrato diante da superveniência da falência, tendo em vista o disposto no citado artigo $75^{26}$ em relação à utilização produtiva dos bens, não sendo, portanto, merecedora de eficácia jurídica erga omnes. Como pode uma cláusula contratual, fruto exclusivamente da autonomia privada e prevista antes da decretação da falência, elidir a preservação do ativo da massa falida?

O juiz, ao decretar a falência, deverá, na sentença, pronunciar-se sobre o lacre do estabelecimento ou a continuação provisória da empresa com o administrador judicial. Caso o julgador tenha adotado a segunda solução, na forma do art. 99, XI, e exista algum bem em poder do falido essencial à sua atividade, cuja posse esteja fundada, por exemplo, em contrato de alienação fiduciária com cláusula resolutiva expressa, a determinação judicial será inócua para impedir a devolução do bem. A simples decretação de falência terá dado ensejo à resolução do contrato e o bem poderá ser alvo de um pedido de restituição ordinária, fulcrado no direito de propriedade, com base no art. 85 .

Deve-se destacar que o interesse na preservação do ativo do falido é de natureza metaindividual; extrapola a relação obrigacional de natureza patrimonial entre credor e devedor. A manutenção dos contratos que permitam a preservação e manutenção dos ativos é uma garantia à massa de credores e um dever do administrador judicial, observados os pressupostos dos arts. 117 e 118.

Destarte, não se pode admitir que uma cláusula, no mais das vezes prevista em contratos de adesão ${ }^{27}$, possa alterar as regras imperativas do concurso de credores.

26 É curial observar o caráter principiológico deste artigo para o legislador, diante da determinação contida no art. 126 de que "nas relações patrimoniais não reguladas expressamente nesta Lei, o juiz decidirá o caso atendendo à unidade, à universalidade do concurso e à igualdade de tratamento dos credores, observado o disposto no art, 75 desta Lei". (grifos nossos)

27 Tal hipótese é muito comum nos contratos de alienação fiduciária em garantia e no contrato de arrendamento mercantil. 
Nesse aspecto, a lei de falências espanhola, em recente reforma promovida pelo Real Decreto-Ley n 3/2009 à Ley n 22/2003 (Ley Concursal), passou a considerar não escrita a cláusula de contratos bilaterais que preveja a decretação da falência como causa de resolução de pleno direito, impondo expressamente a necessidade de manifestação do administrador judicial ${ }^{28}$. Neste sentido também positivou o legislador mexicano no artículo 87 da Ley de Concursos Mercantiles ${ }^{29}$.

Dessa forma, tal qual no direito comparado, deve prevalecer o interesse da massa falida e a função social dos contratos sobre a cláusula resolutiva expressa, pois "o princípio da autonomia privada deve ser revisitado e lido à luz dos valores constitucionais, não sendo possível admitir espécies de zonas francas de atuação da autonomia privada, imunes ao controle axiológico ditado pela Constituição da República" (TEPEDINO, 2009, p. 155).

Com essas considerações, passa-se a análise de alguns contratos em espécie que fundamentam o pedido de restituição, à luz dos princípios da função social do contrato e da utilização produtiva dos bens na falência.

28 Artículo 61. Vigencia de los contratos con obligaciones recíprocas. 1. En los contratos celebrados por el deudor, cuando al momento de la declaración del concurso una de las partes hubiera cumplido integramente sus obligaciones y la otra tuviese pendiente el cumplimiento total o parcial de las recíprocas a su cargo, el crédito o la deuda que corresponda al deudor se incluirá, según proceda, en la masa activa o en la pasiva del concurso. 2. La declaración de concurso, por sí sola, no afectará a la vigencia de los contratos con obligaciones recíprocas pendientes de cumplimiento tanto a cargo del concursado como de la otra parte. Las prestaciones a que esté obligado el concursado se realizarán con cargo a la masa. 3. Se tendrán por no puestas las cláusulas que establezcan la facultad de resolución o la extinción del contrato por la sola causa de la declaración de concurso de cualquiera de las partes. (grifos nossos)

29 Artículo 87. - Se tendrá por no puesta, salvo las excepciones expresamente establecidas en esta Ley, cualquier estipulación contractual que con motivo de la presentación de una solicitud o demanda de concurso mercantil, o de su declaración, establezca modificaciones que agraven para el Comerciante los términos de los contratos. 


\subsection{Alienação fiduciária em garantia}

De origem inglesa ${ }^{30}$, o contrato de alienação fiduciária afigura-se como o contrato de garantia pelo qual o devedor fiduciante transfere o domínio resolúvel de um bem ao credor fiduciário, por força de uma relação creditícia pré-existente ou simultânea, de forma que a posse direta do bem permaneça com o fiduciante e o fiduciário passe a ter a posse indireta (domínio resolúvel) até o pagamento integral da dívida. Em se tornando inadimplente o devedor, poderá o credor alienar o bem objeto do contrato de garantia para satisfazer o seu crédito. Em contrapartida, com a quitação da dívida, resolve-se o domínio do fiduciário, consolidando-se este com o fiduciante.

O legislador brasileiro disciplinou, inicialmente, o contrato de alienação fiduciária em garantia no art. 66 da Lei $n^{\circ} 4.728 / 65$. No entanto, a imprecisão do art. $66, \S 2^{\circ}$, o qual determinava que o devedor permaneceria na posse do bem em nome do fiduciário, tornou ineficaz, sobretudo no aspecto processual, o instituto. As inúmeras controvérsias quanto à ação cabível para que o credor pudesse reaver o bem e, assim, satisfazer o seu crédito (ação de reintegração de posse ou imissão na posse ou, ainda, pela ação de compra e venda com reserva de domínio) maculavam a praticidade e a garantia que o instituto prometia aos credores no tocante à celeridade da recuperação do crédito ou à retomada do bem.

Com o escopo de fortalecer os direitos do credor, o legislador editou o Decreto-Lei n 911/69, alterando a redação original do aludido artigo e determinando que o contrato de alienação fiduciária em garantia transferiria o domínio resolúvel e a posse indireta da coisa ao credor fiduciário, consagrando o desdobramento da posse. Melhor explicita o

30 O contrato de alienação fiduciária em garantia tem por origem o instituto inglês do trust, que teve por escopo opor-se à sistemática aristocrática da Common Law. Tratava-se do meio pelo qual os proprietários rurais ingleses, à época impossibilitados de transmitir por testamento a propriedade, podiam se valer para evitar que, na falta de herdeiros, esta se consolidasse nas mãos do lord (senhor da terra). 
art. $4^{\circ}$ do citado diploma ao determinar que, não sendo possível efetivar a busca e apreensão, seja por não ter sido encontrado o bem alienado fiduciariamente ou por este não se achar na posse do devedor, o procedimento será convertido em ação de depósito.

Outra medida judicial relevante prevista nesse Decreto-Lei, ratificadora dos direitos creditícios do credor, é a restituição (art. $7^{\circ}$ ). 0 dispositivo determina que, na falência do fiduciante, fica assegurado ao credor (proprietário fiduciário) o direito de requerer a restituição do bem, não se submetendo às incertezas do concurso de credores, ao contrário dos credores com garantia real.

Não obstante, fundado no ideal de ampliar as garantias do instituto, sobretudo no que concerne às relações contratuais capitaneadas pelas instituições financeiras, foi editada a Lei $n^{\circ} 10.931 / 2004$, que revogou o mencionado art. 66, passando a regulamentar a matéria o art. 66-B da Lei $n^{\circ} 4.728 / 65$.

Pela nova redação, o contrato de alienação fiduciária em garantia pode abarcar como garantia tanto bens infungíveis como fungíveis (art. $\left.66-\mathrm{B}, \S 3^{\circ}\right)$. O entendimento jurisprudencial anterior está firmado na convicção de que a instituição da garantia fiduciária sobre bem fungível desnaturaria o instituto em questão, pois o bem dado em garantia e objeto de reivindicação poderia ser (e possivelmente seria) diverso daquele originalmente gravado com o ônus, o que, para os tribunais, em sua maioria, representava um contrassenso ${ }^{31}$.

Superada a discussão sobre a nova redação legal, se inadimplida a obrigação creditícia, terá o credor fiduciário o direito de intentar a ação

31 Cf. decisão do Superior Tribunal de Justiça: Processual Civil e Civil. Recurso Especial. Alienação fiduciária em garantia. Ação de busca e apreensão. Ação de consignação em pagamento. Suspensão do processo. Bens fungíveis e consumíveis (comerciáveis). Aplica-se o direito à espécie para manter, por fundamento diverso, a extinção do processo da ação de busca e apreensão, tendo em vista que, em se tratando de bens fungíveis e consumíveis (comerciáveis), é inadmissível a alienação fiduciária e tampouco a ação de busca, apreensão e depósito a que se refere o Decreto-Lei $n^{\circ}$ 911/69. (BRASIL. Superior Tribunal de Justiça. REsp. 346.240/SC. Relator: Ministra Nancy Andrighi. Brasília, 3 de agosto de 2002). 
de busca e apreensão sobre o bem e aliená-lo, independentemente de avaliação prévia, leilão ou qualquer outra medida judicial ou extrajudicial, salvo cláusula contratual em contrário, aportando o preço no pagamento da obrigação e nas eventuais despesas com a realização da garantia, como determina o art. 66-B da Lei $n^{\circ} 4.728 / 65$.

Não obstante, caso o preço obtido para pagamento integral do débito seja insuficiente, permanecerá o credor detentor de um crédito em face do devedor, não mais fiduciário, pois a garantia já fora executada. Entretanto, se o preço da venda for superior em relação à dívida, deverá o credor restituir ao devedor o saldo remanescente acompanhado do demonstrativo da operação realizada.

Sendo o devedor empresário, e diante da superveniente decretação da falência, terá o credor fiduciário o direito de intentar o pedido de restituição, conforme art. $7^{\circ}$. Entretanto, trata-se de simples especificação normativa do Decreto-Lei n 911/69, já que o próprio artigo 85, caput da Lei $n^{\circ} 11.101 / 2005$, abarcaria essa causa de pedir, sendo ambos os dispositivos lastreados pelo direito de propriedade.

Entretanto, sob a vigência do Decreto-Lei n $7.661 / 1945$, caso os bens objetos da alienação fiduciária não fossem encontrados ou não houvessem sido arrecadados pelo juízo falimentar, resolvia-se o crédito no concurso de credores. Esse também era o entendimento do Superior Tribunal de Justiça (STJ) ${ }^{32}$, haja vista que, sob a égide do Decreto-Lei $\mathrm{n}^{\circ}$ 7.661/45, expressamente se exigia a arrecadação prévia do bem para

32 Alienação Fiduciária em Garantia. Ação de Busca e Apreensão. Conversão em Ação de Depósito. Falência da Empresa Fiduciária. Extinção do Processo Sem Resolução de Mérito. Credores Quirografários. 1. Proposta a ação de busca e apreensão antes da decretação de falência do devedor fiduciante, ainda que convertida em ação de depósito, em regra, poderá o credor prosseguir a demanda, substituindo o polo passivo pela massa falida, desde que os bens tenham sido objeto de arrecadação pelo síndico. 2. Todavia, não localizados os bens dados em garantia fiduciária e tampouco arrecadados na falência, o proprietário fiduciário passa a deter um crédito meramente quirografário, regendo-se a controvérsia pela legislação falimentar. (BRASIL. Superior Tribunal de Justiça. REsp. 847.759/MG. Relator: Ministro Luis Felipe Salomão. Brasília, dia 14 de dezembro de 2009). 
que fosse intentado o pedido de restituição, como determinava o art. $76^{33}$.

$\mathrm{Na}$ atual legislação, poderá a restituição ser intentada com ou sem a arrecadação do bem, desde que este esteja na posse do falido quando da decretação da quebra, como determina o art. 85. A atual lei de falências, nesse ponto, evoluiu ao permitir que o terceiro defenda a sua propriedade, independentemente do ato arrecadatório do administrador judicial, isto é, a referência ao bem no inventário, na forma do inciso IV do art.110.

Por estar associado ao direito de propriedade, o pedido de restituição ordinária deve estar devidamente fundamentado, ou seja, trazer em si prova cabal e indiscutível da propriedade, como determina o art. 87, pois não se presta o instituto restituitório a dirimir cizânia quanto à titularidade do domínio. O pedido de restituição tem como único escopo restituir a coisa que esteja na posse da massa falida por fruto da arrecadação ou, excepcionalmente, do falido, quando da decretação de falência.

Incumbe ainda destacar que o credor fiduciário poderá, caso já tenha ingressado com a ação de busca e apreensão, requerer a conversão do procedimento em pedido de restituição, desde que não tenha sido efetivada a medida constritiva da busca. Isso porque por ela retira o bem da posse do devedor, o que inviabiliza a arrecadação pelo administrador judicial. Logo, diante dessa hipótese, não caberá o pedido de restituição por falta de fundamento legal, pois o bem não estará arrecadado nem em posse do falido.

Outro ponto relevante sobre o qual a jurisprudência vem se debruçando é a necessidade ou não de registro do contrato de alienação

33 O STJ chancelava este entendimento: Pedido de Restituição. Bem Alienado Fiduciariamente Não Arrecadado em Poder do Falido. Inviabilidade, Inclusive Quanto a Pretensão de Substituir-se a Coisa Por Dinheiro. Não Tendo Sido Arrecadado o Bem, Por Não Mais Existir ou Por Ter Sido Vendido Antes da Falência, Descabe o Pedido de Restituição. O Privilégio do Credor (Garantia Real) Esgota-se no próprio Bem alienado Fiduciariamente e Não Passa a Outros, Muito Menos ao Dinheiro. Recurso Especial não conhecido. (BRASIL. Superior Tribunal de Justiça. REsp. 39.208/SP. Relator: Ministro Barros Monteiro. Brasília, 14 de fevereiro de 1995). 
fiduciária, junto ao Cartório de Títulos e Documentos competente, para que ele seja eficaz. Nos contratos celebrados no âmbito do Código Civil, a exigência se faz dada a redação do art. 1.361, que prevê a necessidade do registro. Quanto ao contrato firmado no âmbito do sistema financeiro, a Lei $n^{\circ} 4.728 / 1965$, em seu art. 66-B, cuja redação fora dada pela Lei $n^{\circ} 10.931 / 2004$, a exigência parece ser a mesma, visto que a lei faz remissão, nesse ponto, ao Código Civil.

Todavia, a jurisprudência vem solucionando a questão em dois momentos distintos. Prevalece o entendimento segundo o qual não se exige registro para que o contrato de alienação fiduciária seja válido e produza efeitos entre as partes, pois o registro, aqui, serviria como mera formalidade. Por outro lado, somente o registro dará a publicidade exigida para que o contrato produza efeitos perante terceiros não participantes da relação contratual, como na falência. Portanto, seria condição de eficácia do contrato ${ }^{34}$.

Nesse diapasão, o STJ decidiu, em 2010, que a exigência de registro não é requisito de validade do negócio jurídico, pois este vale perfeitamente entre os signatários. Ao revés, só será o negócio oponível a terceiros de boa fé com o registro ${ }^{35}$.

34 Com base neste último fundamento, o Tribunal de Justiça do Estado do Rio de Janeiro negou o pedido de restituição de um bem objeto de contrato de alienação fiduciária em garantia: "Falência. Pedido de restituição. Contrato de abertura de crédito garantido por alienação fiduciária. Possibilidade de o devedor alienar fiduciariamente os bens integrantes de seu patrimônio, cabendo o pedido de restituição. O pedido de restituição dos bens, nessas circunstâncias, só é admissível desde que o contrato tenha sido celebrado e registrado antes do termo legal da falência. O registro do título, conforme exigência do art. 66, da Lei $n^{\circ} 4728 / 65$, no caso da falência, é indispensável para valer contra terceiros, tratando-se de execução coletiva, sob pena de ofensa ao princípio da "par conditio creditorium". Recurso ao qual se nega provimento." (RIO DE JANEIRO. Tribunal de Justiça. Apelação Cível n 2002.001.0868-7. Relator: Desembargador Fernando Cabral. Rio de Janeiro, 25 de junho de 2002).

35 Em seu voto, nos autos do ERESP n² 278.993/SP, o Min. Herman Benjamin, acompanhando o relator Min. Teori Zavascki e o Min. João Otávio de Noronha, assim elucidou a questão: "como é cediço, o contrato de alienação fiduciária somente tem validade perante terceiros depois de devidamente registrado no Cartório, nos moldes ditados pela legislação mencionada. E, por oportuno, esclareça-se: a exigência do registro não é requisito de validade do negócio jurídico em questão. Para as partes signatárias a avença é perfeita e plenamente válida, independentemente do registro que, se ausente, traz como única conseqüência a ineficácia do contrato perante o terceiro de boa-fé, conforme estatuído na própria lei [...]". (BRASIL. Superior Tribunal de Justiça. REsp. 278.993/SP. Relator: Ministro Teori Albino Zavascki. Brasília, 9 de junho de 2010). 
Ultrapassada a divergência e deferido o pedido de restituição pelo juízo da ação que decretou a quebra do devedor, o bem será destacado da massa e alienado nos moldes do art. 66-B da Lei n 4.728/65, já analisado. Restando eventual saldo positivo, deverá o credor satisfeito entregar o respectivo saldo ao administrador judicial da massa falida, que o submeterá ao concurso geral de credores.

No entanto, por vezes o produto da venda não extinguirá toda a dívida e nem saldará as despesas da alienação, nesta hipótese deverá o credor se habilitar na classe dos quirografários, pois já não terá o seu crédito qualquer privilégio em face dos demais credores.

Não obstante, deve-se ressaltar que o aludido pedido de restituição só será possível caso o administrador judicial da massa falida não deseje dar continuidade ao contrato, pois, como nos contratos bilaterais na falência, o administrador judicial pode dar-lhe cumprimento se julgar ser benéfico à massa falida (art. 117 da Lei $n^{\circ}$ 11.101/05). Assim entendendo o administrador judicial, este não deve olvidar esforços para cumprir a avença, haja vista ser a inadimplência causa resolutiva legal do contrato.

Da mesma forma, optando o administrador judicial pela manutenção do contrato, não poderá o bem ser afetado por ato falimentar, visto ser da propriedade de terceiro, e não da massa falida; assim, não poderá o bem, por exemplo, ser alienado pela massa.

Cabe esclarecer que, apesar de se defender essa posição, ela não é unânime na doutrina. Há entendimento no sentido de que a decretação da falência gera o inadimplemento antecipado do contrato pela inequívoca insolvência do devedor, permitindo a retomada do bem pelo credor $^{36}$. Tal argumentação não parece ser verossímil, pois a decretação da falência pressupõe a insolvência do falido, mas, em

36 Esta parece ser a posição de Santos (2001, p. 77), que leciona: "por força do inadimplemento antecipado do contrato, a lei permite ao credor fiduciante retomar a posse do bem alienado fiduciariamente, por meio da ação de restituição". 
contrapartida, não acarreta o inadimplemento do contrato em questão. Pode o contrato ser plenamente adimplido sem que a decretação da falência tenha lhe causado qualquer efeito.

Destarte, com ainda mais razão, não deve o pedido de restituição preceder à manifestação do administrador judicial, como assevera a jurisprudência do STJ ${ }^{37}$.

Por fim, como já elucidado, entende-se que a existência de cláusula contratual tendo a falência como causa resolutiva não deve prevalecer sobre o interesse da massa. Nesse caso, a funcionalidade do pedido de restituição fica subsumida à função social do contrato e ao princípio da otimização (ou maximização) dos ativos do devedor.

\subsection{Contrato estimatório}

Com o advento do Código Civil de 2002, a legislação nacional passou a prever o contrato estimatório como forma típica de contrato. Antes, suas regras se fundavam nas de outros contratos, como o de comissão, o que asseverava a discussão sobre sua natureza jurídica.

De modo a amenizar a discussão, o Código Civil italiano de 1942 tipificou, nos arts. 1.556 a $1.558^{38}$, o contrato estimatório, dando-lhe uma natureza jurídica própria, autônoma, adotada pelo Código Civil brasileiro nos arts. 534 a 537.

37 Comercial. Falência. Contrato Garantido por Alienação Fiduciária. Se, até a data da quebra, as respectivas obrigações estavam sendo rigorosamente cumpridas, a massa falida pode optar pelo cumprimento do contrato (DL 7.661/45, art. 43). Antes da interpelação do síndico para que declare se cumpre ou não o contrato, o pedido de restituição do bem alienado fiduciariamente é prematuro. Recurso especial não conhecido. (BRASIL, Superior Tribunal de Justiça. REsp.172.367/PR. Relator: Ministro Ari Pargendler. Brasília, 30 de abril de 2002).

38 "Art. 1556. Nozione: Con il contratto estimatorio una parte consegna una o più cose mobili all'altra e questa si obbliga a pagare il prezzo, salvo che restituisca le cose nel termine stabilito. Art. 1557. Impossibilità di restituzione: Chi ha ricevuto le cose non è liberato dall'obbligo di pagarne il prezzo, se la restituzione di esse nella loro integrità è divenuta impossibile per causa a lui non imputabile. Art. 1558. Disponibilità delle cose: Sono validi gli atti di disposizione compiuti da chi ha ricevuto le cose; ma i suoi creditori non possono sottoporle a pignoramento o a sequestro finché non ne sia stato pagato il prezzo. Colui che ha consegnato le cose non può disporne fino a che non gli siano restituite." 
Dessa forma, define Souza (2004, p. 57) que o contrato estimatório é "aquele pelo qual uma pessoa recebe de outra, coisa móvel, com a obrigação de restituí-la ou pagar em prazo certo o preço estimado, tendo a faculdade de disposição da mesma". Em outras palavras, uma parte entrega um bem de sua propriedade a outra para que esta pague determinado preço estipulado ou devolva a coisa na forma e estado em que a recebeu.

Com efeito, ocorrendo a falência do consignatário, cabe ao consignante intentar o pedido de restituição, com base no art. 85 da Lei $n^{\circ} 11.101 / 2005$, para reaver a coisa, pois somente os bens do falido compõem a garantia dos credores, e não os de terceiros.

Aarrecadação na falência poderia ser obstada, a priori, pelo art. 536 do Código Civil, que veda a constituição de penhora ou sequestro sobre o bem consignado enquanto o preço não for pago. Assim, com muito mais razão seria a impossibilidade de arrecadação pelo administrador desses bens que compõem o patrimônio do consignante, e não do consignatário. Dessa forma também conclui Simionato (2008). ${ }^{39}$

No entanto, tal solução não parece adequada, pois, como se infere do art. 110 da Lei $n^{\circ} 11.101 / 2005$, os bens que forem de propriedade de terceiros serão elencados no inventário de arrecadação, ou seja, o administrador judicial deve arrecadar os bens que sabidamente não compõem a massa falida ${ }^{40}$. Trata-se de uma regra de proteção ao concurso de credores. A arrecadação indiscriminada dos bens que forem encontrados com o falido assegura, ou pretende assegurar, aos

39 Ademais, confirma o título de propriedade do consignante que a coisa consignada não pode ser objeto de penhora ou sequestro pelos credores do consignatário enquanto não pago integralmente o preço (art. 536, Código Civil). Se a coisa não pode ser objeto de penhora ou sequestro, mais ainda não poderá ser arrecadada na falência do consignatário, cabendo o pedido de restituição como legitimo proprietário (SIMIONATO, 2008).

${ }^{40}$ Advirta-se que a Lei $n^{\circ} 11.101 / 2005$ prevê casos de exclusão de certos bens da arrecadação, como aqueles absolutamente impenhoráveis (art. 108, $\S 4^{\circ}$ ) e os constituídos como patrimônio de afetação para o cumprimento de destinação específica (art. 119, IX). 
credores que todo o ativo do falido será destinado ao adimplemento dos seus respectivos créditos. Assim também decidiu o STJ41.

Deve-se atentar que cabe ao administrador judicial pronunciar-se sobre a continuação ou não do contrato para efeitos de restituição, com base no art. 117 da Lei $n^{\circ} 11.101 / 05$, ainda que subsista a previsão de cláusula resolutiva expressa.

Tome-se como ilustração um contrato estimatório firmado para a venda de 10.000 (dez mil) barris de petróleo no valor total de $\mathrm{R} \$$ $18.000,00$ (dezoito mil reais) e nesse período sobrevém a falência do consignatário. Coincidentemente, no mesmo momento, há uma crise de desabastecimento e o barril tem o seu valor triplicado. Nessa hipótese, mais vale ao administrador judicial dar prosseguimento ao contrato, vendendo o bem por um valor bastante acima do estipulado e entregando a quantia estipulada ao consignante do que optar pela resolução do contrato e consequente entrega do bem. Melhor será, pois se estará reduzindo o passivo da massa falida, uma das diretrizes do art. 117, para o administrador judicial dar cumprimento aos contratos bilaterais ${ }^{42}$.

Além de fundamentar o pedido de restituição com a comprovação da propriedade, o autor deve, na petição inicial, descrever a coisa reclamada, pois não cabe a medida para entrega de coisa indeterminada.

41 Direito Comercial. Falência. Pedido de Restituição de Dinheiro. Alienação de Mercadorias Recebidas em Consignação Antes da Quebra. Contabilização Indevida pela Falida do Valor Equivalente às Mercadorias. Dever da Massa Restituir ou as Mercadorias ou o Equivalente em Dinheiro. Súmula 417 do STF. 1- O que caracteriza o contrato de venda em consignação, também denominado pela doutrina e pelo atual Código Civil (arts. 534 a 537) de contrato estimatório, é que (i) a propriedade da coisa entregue para venda não transferida ao consignatário e que, após recebida a coisa, o consignatário assume uma obrigação alternativa de restituir a coisa ou pagar o preço dela ao consignante. 3- Se o consignatário vendeu as mercadorias entregues antes da decretação da sua falência e recebeu o dinheiro da venda, inclusive contabilizando-o indevidamente, deve devolver o valor devidamente corrigido ao consignante. Incidência da Súmula n. ${ }^{\circ} 417$ do STF. 4- A arrecadação da coisa não é fator de obstaculização do pedido de restituição em dinheiro quando a alienação da mercadoria é feita pelo comerciante anteriormente à decretação da sua quebra. (BRASIL. Superior Tribunal de Justiça. REsp. 710.658/RJ. Relator: Ministra Nancy Andrighi. Brasília, 26 de agosto de 2005).

42 Da mesma forma aponta Valverde (2001, p. 54), ainda sob a vigência do Decreto-Lei $n^{\circ}$ $7.661 / 45$, ao lecionar que "sobrevindo a falência, tem o consignante o direito, se o síndico [hoje administrador judicial] não mantiver o contrato, de reclamar a restituição da coisa". 
A primazia fundamental ligada ao pedido de restituição mostra a importância da descrição do bem e a preocupação de se ater ao princípio da devolução in natura, sem prejudicar outros interesses em disputa nas restituições especiais ou em dinheiro.

A importância de determinado bem no acervo da massa falida pode comprometer a continuidade da atividade empresária quando determinada a restituição pelo juízo. Nesse diapasão, um pedido de restituição mal formulado e negligentemente deferido pode engessar ou até impossibilitar a continuação da empresa pelo administrador judicial, prejudicando o concurso de credores, que possivelmente terá a sua garantia, qual seja, os bens do falido, deteriorados e/ou em menor contingente.

Dessa forma, a exigência legal de fundamentação, descrição do bem e manifestação ou não oposição do administrador judicial se mostram em plena conformidade com a "otimização" e utilização produtiva dos bens do falido.

\subsection{Arrendamento mercantil}

De origem norte-americana, o contrato de arrendamento mercantil, ou leasing, pode ser conceituado genericamente como o contrato pelo qual uma das partes, pretendendo utilizar um bem, indica-o a uma pessoa denominada arrendador (instituição financeira) para que ela o adquira e o alugue posteriormente ao primeiro. Destarte, representa um forte instrumento de financiamento à aquisição de bens ou sua utilização produtiva, pois permite que o agente econômico aproveite o bem sem que, para tal, precise reduzir substancialmente o capital de giro da sociedade. Isso ganha ainda mais relevância quando se associa a coisa arrendada aos bens sujeitos a um maior desgaste (como aeronaves, veículos automotores, máquinas e equipamentos com tecnologia sujeita à rápida obsolescência), nos quais o arrendatário precisa promover constantes substituições.

Cabe ao arrendatário pagar o aluguel ajustado e conservar o bem; já o arrendador tem a obrigação de resguardar a posse mansa 
e pacífica do bem ao primeiro durante a vigência do contrato. Como aponta Pereira (2009), ao final do prazo estipulado, cabe ao arrendatário uma tríplice alternativa: (i) restituir a coisa, (ii) renovar o contrato ou (iii) adquirir o bem pelo valor estipulado no contrato ${ }^{43}$. A possibilidade de aquisição do bem foi o que alavancou o instituto na seara empresarial e, posteriormente, no campo jurídico.

O arrendamento mercantil ${ }^{44}$, apesar de facilitar o acesso ao crédito, não dá ao arrendatário a segurança jurídica que um proprietário tem, haja vista que não há transferência de propriedade. Por conseguinte, o arrendatário poderá ser privado repentinamente de um bem essencial à sua atividade caso se torne inadimplente.

No ordenamento pátrio, o contrato de arrendamento mercantil foi disciplinado parcialmente pela Lei $n^{\circ} 6.099$, de 12 de setembro de 1974, que apenas definiu o tratamento tributário da relação contratual, sendo esta regulamentada inicialmente pela Resolução $n^{\circ} 351 / 1975$, do Conselho Monetário Nacional, revogada pela Resolução n 980/1984, e esta, pela Resolução $n^{\circ}$ 2.309/96. Em sua redação original, o contrato de arrendamento mercantil só podia ser celebrado por pessoa jurídica. No entanto, com a edição da Lei $n^{\circ} 7.123 / 1983$, que deu nova redação ao art. $1^{\circ}$ da Lei $n^{\circ} 6.099 / 74$, passou-se a admitir que pessoas físicas assumissem a posição de arrendatário. Não obstante,

43 Na lição de Pereira (2009, p. 202) caberá ao arrendador: "a) restituir a coisa ao arrendador, respondendo pelos danos que a mesma sofrer, salvo a deterioração advinda do uso regular; b) renovar o contrato, com o mesmo objeto ou outro de características iguais ou semelhantes; c) adquirir o bem pelo valor previsto no contrato, o qual consiste na pré-fixação de um preço que leva em consideração o uso da coisa pelo arrendatário e os pagamentos percebidos pelo arrendador (valor residual)".

44 Este ato de que decorre o arrendamento mercantil tem três figuras, tradicionalmente: o arrendador ou a arrendadora, o arrendatário e o fornecedor do bem, definidos na lição de Venosa (2006, p. 572): "Arrendador é a empresa de leasing, de atuação financeira, com objetivo assim expresso nos estatutos sociais, conforme nosso Direito, que se encarrega de arrendar o bem ao arrendatário. Ressalte-se que a empresa de leasing deve ter autorização do Banco Central do Brasil para funcionamento e está sob fiscalização dessa autarquia. Arrendatário é o sujeito que, tendo necessidade de um bem móvel ou imóvel, dele se utiliza sob essa modalidade. $\mathrm{O}$ fornecedor do bem é o terceiro sujeito envolvido no negócio. Trata-se do alienante do bem encomendado pelo arrendatário à arrecadante. Não participa necessariamente do contrato". 
a figura do arrendador ainda é reservada às pessoas jurídicas, mais especificadamente às instituições financeiras sujeitas à fiscalização e controle do Banco Central ${ }^{45}$.

A despeito da regulamentação legal, a característica primordial e que constitui a principal garantia do contrato é a manutenção da propriedade nas mãos do arrendador. Tal afirmativa ganha relevância no caso de decretação da falência do arrendatário. Nessa hipótese, pode o arrendador intentar o pedido de restituição para reaver o bem, já que ele é de sua propriedade. No entanto, como aponta Campinho (2009, p. 394), para tal, deverá provar "não só a titularidade sobre a coisa, mas também a posse ilegítima da massa falida".

Nesse diapasão, como em todo contrato bilateral, pode o administrador judicial entender pelo cumprimento do contrato, na forma do art. 117 da Lei $n^{0} 11.101 / 2005$. Nessa hipótese, não há que se falar em restituição, pois não estará a massa falida na posse legal do bem, e sim em virtude de contrato. No entanto, caso o contrato seja resolvido pela declaração negativa ou silêncio do administrador judicial, abre-se ao arrendador a possibilidade de ingressar com o pedido de restituição no juízo que decretou a quebra.

Pode ainda, e hoje é cada vez mais comum, o contrato de arrendamento mercantil dispor que, em caso de falência, haverá resolução de pleno direito, hipótese em que não se perquiriria a vontade do administrador judicial. No entanto, entende-se que tal disposição, a qual assegura a funcionalidade do pedido de restituição, não deve prevalecer sob o interesse da massa falida e do concurso de credores, com sua subsunção à função social do contrato, sendo, assim, a cláusula resolutiva ineficaz perante a massa falida.

45 Cf. art. $4^{\circ}$ da Resolução $n^{\circ} 2.309 / 96$, que impõe a forma jurídica de sociedades anônimas às sociedades arrendadoras, devendo constar obrigatoriamente de sua denominação a expressão "Arrendamento Mercantil". 
Não obstante, pela própria natureza do contrato de arrendamento mercantil, entendendo o administrador judicial pelo cumprimento do contrato, ele está obrigado a adimpli-lo e o crédito será considerado extraconcursal para fins de pagamento (art.84, V). Em caso de mora da massa falida, estará o arrendador autorizado a rescindir o contrato e intentar o pedido de restituição ordinária, com base no art. 85 .

Esse também foi o entendimento do Tribunal de Justiça do Estado do Rio de Janeiro, ainda sob a égide do Decreto-Lei $n^{\circ} 7.661 / 1945$, mas que muito se amolda à atual disposição legal ${ }^{46}$.

Ressalta-se, por fim, como já apontava Mendonça (1934, p. 290), que "o proprietário não pode reivindicar a importância de rendas ou de alugueis não pagos", cabendo-lhe apenas se habilitar na falência, submetendo-se ao concurso de credores, sob o manto da par conditio creditorum.

46 Falência. Arrendamento mercantil sob forma de leasing. Pedido de restituição. Art. 76 da L.F. Trata-se de contrato de locação mercantil de quatro caminhões basculantes, sob a forma de leasing. Como se sabe, o leasing é um contrato bilateral, complexo e comutativo e, se se trata de um contrato, dispõe o art. 43 da L.F [correspondente ao art. 117 da Lei $n^{\circ} 11.101 / 2005$ ] que "os contratos bilaterais não se resolvem pela falência e podem ser executados pelo síndico, se achar de conveniência para a massa". Cabe ao síndico, portanto, informar à outra parte contratante que pretende continuar com o negócio, cumprindo suas cláusulas, se for do interesse da Massa. Por seu turno, se nenhuma providência for tomada pelo síndico, o contraente pode interpelá-lo para que esclareça se pretende manter o contrato em vigor (par. único do art. 43). Não se pode romper um contrato de arrendamento mercantil se o art. 43 da L.F. dispõe que ele não se resolve com a falência e se o síndico sequer se manifestou sobre a conveniência do cumprimento dele. Portanto, a decretação da falência não induz ao rompimento do contrato de arrendamento mercantil, salvo se houver mora ou declaração expressa do síndico de que não pretende dar continuidade ao contrato, casos em que poderá a arrendadora requerer a restituição. Agravo rejeitado. Asseverou ainda, em seu voto, o desembargador Gustavo Kuhl Leite: "não se vislumbra como se possa romper um contrato de arrendamento mercantil se o art. 43 da L.F. dispõe que ele não se resolve com a falência e se, por outro lado, o síndico sequer se manifestou sobre a conveniência do cumprimento dele. Ademais, acresce observar que foi concedida a continuação do negócio, em caráter excepcional, e o objeto social da falida é, exatamente, o transporte de coisas, de forma que é de toda conveniência, não só para a Massa como, e principalmente, para os seus credores, que a falência possa ser levantada, o que, por certo, não ocorrerá se forem retirados os veículos que constituem o instrumento de trabalho da empresa. Fique claro, contudo, que se ocorrer mora no pagamento das prestações e depois do síndico ter assumido o compromisso de dar cumprimento ao contrato, poderá a arrendadora, então, ingressar com o pedido de restituição." (grifos nossos) (RIO DE JANEIRO. Tribunal de Justiça. Agravo de Instrumento ${ }^{\circ}$ 2.016. Relator: Desembargador Gustavo Kuhl Leite. Rio de Janeiro, 21 de outubro de 1997). 


\subsection{Comodato}

O contrato de comodato, apresentado por vezes sob o titulo de empréstimo, possui disciplina própria no Código Civil pátrio, no art. 579, sendo definido como "o empréstimo gratuito de coisas não fungíveis". Em outras palavras, é o contrato pelo qual uma pessoa transfere gratuitamente a outrem um bem infungível para que essa dele se utilize e depois promova sua restituição.

É importante diferenciar o contrato de mútuo do contrato de comodato, já que ambos são apresentados como espécies típicas de empréstimo.

No contrato de mútuo, o mutuário recebe a propriedade da coisa a ele emprestada pelo mutuante, por isso é conhecido como empréstimo de consumo. Não há repartição da posse em direta e indireta. $\mathrm{O}$ objeto do mútuo há de ser fungível, daí emerge a harmonização com a transmissão do domínio (art. 587 do Código Civil). A obrigação de restituir recai em um bem de mesmo gênero, qualidade e quantidade, e não propriamente o mesmo bem que foi objeto do empréstimo, pois este, no mais das vezes, já foi consumido.

Em contrapartida, no comodato, o comodante transfere apenas a posse do bem ao comodatário, permanecendo com o domínio. Aqui, há a repartição da posse: o comodatário possui a posse direta sobre o bem, ao passo que o comodante permanece com a posse indireta, já que é o proprietário. Nessa hipótese, deverá o comodatário restituir exatamente o que foi dado em empréstimo, pois este não se prestou ao consumo, e sim ao uso. Por isso é conhecido o comodato como empréstimo de uso.

Essa distinção tem reflexo primordial quanto ao pedido de restituição, pois ele só terá cabimento no contrato de comodato. Isso porque somente o comodante permanece como proprietário do bem, pressuposto subjetivo para a ação restitutória. Sobrevindo a falência do comodatário, poderá o comodante intentar o pedido de restituição. Entretanto, esse pedido estaria ou não condicionado à manifestação do administrador judicial pelo cumprimento do contrato? 
O Decreto-Lei 7.661/1945 não continha dispositivo próprio para os contratos unilaterais ${ }^{47}$. Assim, por falta de regulamentação legal específica e através de uma interpretação a contrário sensu do art. $43^{48}$, apenas os contratos bilaterais eram poupados da resolução ope legis, isto é, por efeito da decretação de falência. Aos contratos unilaterais, sendo o falido devedor, importaria a resolução antecipada na data da decretação de falência (art. 25).

A lei vigente inovou nessa matéria ao dispor, em seu art. 118, que o administrador judicial poderá dar prosseguimento aos contratos unilaterais, desde que conte com a anuência do Comitê de Credores ${ }^{49}$. Não consentindo o Comitê, o contrato se resolveria tal qual no regramento anterior, devendo o comodante intentar o pedido de restituição com base no art. 85, caput. Como o Comitê de Credores não é um órgão obrigatório nos processos de falência, em não havendo, determina o art. 28 que as suas atribuições sejam conferidas ao administrador judicial ou ao juiz, em caso de incompatibilidade.

A existência de cláusula contratual prevendo a resolução do contrato em caso de falência do comodatário enseja ao comodante o manejo da ação de restituição para reaver o bem de sua propriedade. Como aponta Valverde (2001, p. 58) ao definir contrato de comodato: "são contratos que não se rescindem com a falência, salvo cláusula expressa em contrário".

Nesse ponto, valem os comentários anteriores sobre a preservação e otimização da utilização produtiva dos bens que se contrapõem à resolução expressa do contrato por uma cláusula.

47 Majoritariamente, se não unânime, a doutrina e a jurisprudência entendem que o contrato de comodato é um contrato unilateral. Como leciona Sílvio de Salvo Venosa (2006, p.180), o comodato é "um contrato unilateral gratuito por meio do qual o comodante entrega bem não fungível para uso ao comodatário, o qual deve devolvê-lo após o tempo certo".

48 "Art. 43: Os contratos bilaterais não se resolvem pela falência e podem ser executados pelo síndico, se achar de conveniência para a massa."

49 Para Campinho (2009, p. 395): "não sendo deferida a continuação provisória do negócio, não há mais atividade comercial entre as partes a justificar a permanência do empréstimo. Sendo ela deferida, caberá ao administrador judicial pronunciar-se a respeito da execução do contrato". 
Ademais, o pensamento do citado autor foi revelado na vigência do Decreto-Lei $n^{\circ} 7.661 / 45$, quando não existia dispositivo específico para os contratos unilaterais nem dispositivo idêntico ou análogo ao art. 75, que é principiológico, como já afirmado.

Destaca-se que, com o simples recebimento do pedido de restituição, fica suspensa a disponibilidade da coisa até o trânsito em julgado da sentença, como determina o art. 91 da Lei n 11.101/2005. Destarte, deverá o administrador, tão logo tenha conhecimento da ação, sustar todos os atos que importem na alienação do bem objeto da demanda. Isso se justifica pela necessidade de se conferir efetividade e funcionalidade ao instituto restitutório, pois se assim não fosse, o bem poderia ser alienado, mesmo já reconhecido o direito à restituição, o que não se pode admitir.

Julgada procedente a ação de restituição, o juiz determinará a entrega da coisa no prazo de 48 horas, na forma do art. 88, desde que o autor tenha ressarcido a massa falida ou quem tiver suportado as despesas incorridas com a conservação da coisa reclamada ${ }^{50}$. Contudo, não sendo ressarcida, poderá a massa ou quem estiver com o bem retê-lo até o pagamento das referidas despesas, por uma interpretação analógica e sistemática do art. 644 do Código Civil, já que, nessa hipótese, funcionou a massa falida ou o terceiro como depositário legal da coisa ao qual se legitima o direito de retenção.

Julgado improcedente o pedido, poderá o juiz determinar a sua inclusão no quadro geral de credores caso seja comprovada a

50 Neste prisma, dispõe a Ley de Concursos Mercantiles mexicana, em seu art. 73, in verbis: "Artículo 73 - La separación estará subordinada a que el separatista dé cumplimiento previo a las obligaciones que con motivo de los bienes tuviere.

En los casos de separación por parte del enajenante que hubiere recibido parte del precio, la separación estará condicionada a la devolución previa de la parte del precio recibido. La restitución del precio será proporcional a su importe total, en relación con la cantidad o número de los bienes separados.

El vendedor y los demás separatistas tienen la obligación previa de reintegrar todo lo que se hubiere pagado o se adeude por derechos fiscales, transporte, comisión, seguro, avería gruesa y gastos de conservación de los bienes". 
existência de uma relação creditícia, conforme estabelece o art. 88. Se, no entanto, o autor não demonstrar o direito sobre a coisa ou sequer comprovar o seu crédito, será o pedido julgado improcedente, com a respectiva condenação do autor ao pagamento das custas e honorários advocatícios.

Essa disposição legal é salutar e célere, pois dispensa ao credor a necessidade de intentar uma nova medida judicial para que tenha o seu crédito habilitado. Nesse ponto, a lei vigente evoluiu em relação à anterior, que facultava ao juiz a inclusão. Pela nova redação, o juiz está obrigado a determinar a inclusão se comprovada a existência de crédito em favor do autor vencido.

\section{Conclusão}

Como elucidado, o pedido de restituição é um meio processual que permite ao terceiro reaver o bem de sua propriedade, arrecadado na falência ou que esteja na posse do devedor quando da decretação da falência. O direito constitucional de propriedade permite ao dono da coisa reaver o bem de quem injustamente o possua, como ocorre nessas hipóteses.

Trata-se de um incidente processual em que o terceiro reivindicante deve comprovar a sua condição de proprietário, pois, como visto, não é compatível com o rito processual do pedido de restituição a aferição do domínio; esta deve ser dirimida numa ação autônoma.

Além de se provar a propriedade, é preciso a comprovação da posse injusta pela massa falida, pois, do contrário, o terceiro deve ser tido como credor, submetendo-se à execução concursal instaurada pela decretação de falência. Dessa forma, foram analisadas algumas espécies contratuais em que a regularidade da posse da massa falida deverá ser aferida.

Considerando-se o estudo do contrato de alienação fiduciária, por exemplo, pode-se concluir que a restituição só será devida se houver o inadimplemento pela massa falida das parcelas devidas em virtude do 
contrato, pois é o inadimplemento causa de extinção de pleno direito do contrato e de consequente consolidação da propriedade nas mãos do credor fiduciário.

Já no contrato de comodato, o pedido de restituição não será viável simplesmente pela decretação da falência. A resolução contratual só se dará se o administrador judicial não diligenciar por cumprir o contrato. Por se tratar de um contrato unilateral, é o administrador quem deve se aprontar ao cumprimento do contrato, valendo a sua inércia como anuência à resolução do contrato. Isso ocorrerá se não for deferida a continuação provisória das atividades do falido, quando a manutenção do empréstimo não mais se justificará. Resolvido o contrato, cabe ao comodante, proprietário do bem, intentar o pedido de restituição ordinária.

Por outro lado, no contrato estimatório, ocorrendo a falência do consignatário, é o administrador judicial que se manifestará sobre o cumprimento do contrato quando instado pelo consignante. Entendendo pela resolução do contrato, poderá o proprietário do bem consignado promover a ação restituitória.

Estudou-se ainda o pedido de restituição no contrato de arrendamento mercantil. Decretada a falência do arrendatário, a princípio, caberá o pedido de restituição pelo arrendador, já que este não transferiu a propriedade do bem, mas, como aludido, isso dependerá da manifestação do administrador judicial ou do inadimplemento da obrigação, pois os contratos bilaterais não se resolvem com a falência, conforme o art. 117.

A exigência de manifestação do administrador judicial, como analisado, não se esvazia nem com a previsão contratual de resolução expressa pela decretação da falência de uma das partes contratantes. Isso porque, por vezes, tal cláusula impossibilitará a manutenção da unidade produtiva que tem por escopo preservar e "otimizar" os bens arrecadados para serem alienados e, posteriormente, adimplir as dívidas do falido o quanto for possível. 
Ademais, a função social dos contratos impõe que os contratantes assumam um "compromisso" com toda a sociedade de perseguir um fim socialmente útil, e não apenas os interesses individuais. Dessa forma, a cláusula resolutiva expressa deve ser entendida como ineficaz, por não dar azo à concretização da função social exigida dos contratos e ir de encontro à inteligência do art. 75 do regramento falimentar.

Dessa forma, o objetivo do trabalho foi apresentar, numa visão crítica, as nuanças do instituto restitutório, buscando, de forma precisa, delinear e apresentar as divergências doutrinárias e, sobretudo, compatibilizar o instituto que legitimamente se presta a interesses privados aos demais preceitos constitucionais, subsumido à função social dos contratos e da empresa, ainda que em estado de falência.

\section{Referências}

ABRÃO, Nelson. O novo direito falimentar. São Paulo: Revista dos Tribunais, 1985.

ABRÃO, Carlos Henrique. Pedido de restituição na concordata e na falência. 1990, 273 f. Tese (Doutorado em Direito Comercial)-Faculdade de Direito, Universidade de São Paulo, São Paulo,1990.

BEZERRA FILHO, Manuel Justino. Lei de recuperação de empresas e falências comentada. São Paulo: Revista dos Tribunais, 2009.

BRASIL.SuperiorTribunalde Justiça.Açãodebuscaeapreensãointentada antes da decretação da falência, possibilidade de prosseguimento da demanda. REsp. 847.759MMG. Recorrente: Banco Itaú S\A. Recorrida: Alis Engenharia SIA. Relator: Ministro Luis Felipe Salomão. Brasília. Diário da Justiça Eletrônico, 14 dez. 2009. Disponível em: <https:// ww2.stj.jus.br/revistaeletronica/ita.asp?registro=200601089074\&dt_ publicacao=14/12/2009>. Acesso em: 14 dez. 2012.

BRASIL. Superior Tribunal de Justiça. Ação de busca e apreensão, bem fungível objeto de contrato de alienação fiduciária em garantia. REsp. 346.240 ISC. Recorrente: Banco do estado de Santa Catarina SIA - BESC. Recorrida: Adipar Distribuidora de Parafusos Ltda. 
Relator: Ministra Nancy Andrighi. Diário da Justiça, Brasília, DF, 4 nov. 2002. Disponível em: <https://ww2.stj.jus.br/revistaeletronica/ita. asp? registro=200101099150\&dt_publicacao=04/11/2002>. Acesso em: 14 dez. 2012.

BRASIL. Superior Tribunal de Justiça. Alienação fiduciária, inexigibilidade de registro. REsp. 278.993।SP. Recorrente: Sindicato dos Notários e Registradores do estado de São Paulo. Recorrida: Fazenda do estado de São Paulo. Relator: Ministro Teori Albino Zavascki. Brasília. Diário da Justiça Eletrônico, 9 jun. 2010. Disponível em: <https:// ww2.stj.jus.br/revistaeletronica/ita.asp?registro=200300379372\&dt publicacao=30/06/2010 > . Acesso em: 10 dez. 2012.

BRASIL. Superior Tribunal de Justiça. Pedido de restituição bem fiduciariamente alienado, bem não arrecadado. REsp. 39.208ISP. Recorrente: Banco da Amazônia SIA. Recorrida: Eletro Tec Industria e Comercio Ltda. - Massa Falida. relator: Ministro Barros Monteiro. Diário da Justiça, Brasília, DF, p. 7164, 27 mar. 1995.

BRASIL. Superior Tribunal de Justiça. Pedido de restituição de bem objeto de contrato alienação fiduciária em garantia. REsp. 172.367\ PR. Recorrente: Banco do Brasil S\A. Recorrida: Madeira Karson do Pará Ltda. - Falida. Relator: Ministro Ari Pargendler. Diário da Justiça, Brasília, DF, p. 294, 24 jun.2002.

BRASIL. Superior Tribunal de Justiça. Pedido de restituição de bem objeto de contrato estimatório alienados antes da decretação da quebra. REsp.710.658\RJ. Recorrente: Lundgren Irmãos Tecidos, Indústria e Comércio S\A. Recorrida: Grandelar Indústria Metalúrgica. Relator: Ministra Nancy Andrighi. Diário da Justiça, Brasília, DF, p. 373, 26 set. 2005.

BRASIL. Tribunal de Justiça do Estado do Rio de janeiro. Arrendamento Mercantil, falência, resolução contratual. Agravo de Instrumento $n^{\circ}$ 2.016. Recorrente: Nacional Leasing S\A. - Arrendamento Mercantil. Recorrido: Expresso Sul Fluminense Ltda. Relator: Desembargador Gustavo Kuhl Leite. Rio de Janeiro, dia 21 out. 1997. Disponível em: <http://www1.tjrj.jus.br/gedcacheweb/default.aspx?UZIP=1\&GEDID= 00037BDB0E800E7C6C7EAEC44261026FDF6A0EBEC30A1305>. Acesso em: 13 dez. 2012. 
BRASIL. Tribunal de Justiça do Estado do Rio de Janeiro. Pedido de restituição de bens móveis, alienação fiduciária, registro. Apelação Cível n² 2002.001.0868-7. Recorrente: Banco do Brasil S\A. Recorrida: Massa Falida de Transglobo Indústria e Comércio S\A. Relator: Desembargador Fernando Cabral. Rio de Janeiro, dia 25 de jun. 2002. Disponível em: <http://www1.tjrj.jus.br/gedcacheweb/default.aspx? UZIP=1\&GEDID=0003D4BE718F46BE4A42C445029C0DD4935CE 4C402453218>. Acesso em: 13 dez. 2012.

BULGARELLI, Waldirio. Contratos mercantis. 7. ed. São Paulo: Atlas, 1993.

CAHALI, Yussef Said (Coord.). Contratos nominados: doutrina e jurisprudência. São Paulo: Saraiva, 1995.

CAMPINHO, Sérgio. Falência e recuperação de empresa. 4. ed. Rio de Janeiro: Renovar, 2009.

COELHO, Fábio Ulhoa. Curso de direito comercial. 7. ed. São Paulo: Saraiva, 2007. v. 3.

FAZZIO JÚNIOR, Waldo. Lei de falências e concordatas comentada. 3. ed. São Paulo: Atlas, 2003.

FERREIRA, Waldemar Martins. Tratado de direito comercial. São Paulo: Saraiva, 1966. v. XV.

FERREIRA, Waldemar Martins. Questões de direito comercial. 2. ed. São Paulo: Max Limonad, 1932.

GOMES, Orlando. Direito civil: contratos. 26. ed. Rio de janeiro: Forense, 2008.

LACERDA, José Cândido Sampaio de. Manual de direito falimentar. 2. ed. Rio de Janeiro: Freitas Bastos, 1961.

MARTINS, Fran. Contratos e obrigações comerciais. 3. ed. Rio de Janeiro: Forense, 1993.

MENDONÇA, José Xavier Carvalho. Tratado de direito comercial brasileiro. Rio de Janeiro: Freitas Bastos, 1934. v. VIII. 
PEREIRA, Caio Mário da Silva. Instituições de direito civil: contratos. Rio de Janeiro: Forense, 2009. v. III.

REQUIÃO, Rubens. Curso de direito falimentar. São Paulo: Saraiva, 1998. v. I.

SALLES JÚNIOR, Marcos Paulo de Almeida Souza. Do pedido de restituição. In: SOUZA JUNIOR, Francisco Satiro de; PITOMBO, Antônio Sérgio A. de Moraes (Coord.). Comentários à lei de recuperação de empresas e falência. São Paulo: Revista dos Tribunais, 2007. pp. 377397.

SANTOS, Joaquim Antônio Penalva. Obrigações e contratos na falência. 2. ed. Rio de Janeiro: Renovar, 2003.

SANTOS, Paulo Penalva (Coord.). A nova lei de falências e de recuperação de empresas: Lei $n^{\circ} 11.101 / 05$. Rio de Janeiro: Forense, 2007.

SIMIONATO, Frederico Augusto Monte. Tratado de direito falimentar. Rio de Janeiro: Forense, 2008.

TEPEDINO, Gustavo José Mendes. Temas de direito civil. Rio de Janeiro: Renovar, 2009. t. III.

TEXEIRA, Sálvio de Figueiredo (Coord.). Comentários ao novo código civil. Rio de Janeiro: Forense, 2004. v. VIII.

THEODORO JÚNIOR, Humberto. O contrato e sua função social. Rio de Janeiro: Forense, 2003.

VALVERDE, Trajano de Miranda. Comentários à lei de falências. Rio de Janeiro: Forense, 2001. v. II.

VENOSA, Sílvio de Salvo. Direito civil: contratos em espécie. São Paulo: Atlas, 2006.

Recebido em: 10/12/12

Aprovado em: 24/01/13 